\section{KẾT LUẬN}

Mặc dù, tiến hành trên cõ̃ mẫu khá nhỏ 05 bệnh nhân, nhưng nghiên cứu của chúng tôi bước đầu cho thấy những kết quả đầy hứa hẹn trong việc ứng dụng tế bào miễn dịch tự thân NK trong sự cải thiện chất lượng cuộc sống của bệnh nhân ung thư phổi giai đoạn cuối - một trong những vấn đề quan trọng nhất đối với nhóm bệnh nhân này. Chúng tôi hy vọng rằng, đây sẽ là tiền đề để chúng tôi tiến hành nghiên cứu trên một nhóm bệnh nhân lớn hơn với nhiều nhóm bênh nhân ung thư hơn nữa để phản ánh một cách toàn diện hơn nữa giá trị của liệu pháp này. Đem đến nhiều niềm tin và hy vọng hơn nữa cho bệnh nhân ung thư những người đang phải trải qua những đau đớn và mệt mỏi vì căn bệnh nan y này.

LờI CAM ƠN. Kết quả nghiên cứu này thuộc đề tài cấp nhà nước "Nghiên cứu sử dụng tế bào miễn dịch tự thân gamma delta $T(\gamma \delta T)$ và diệt tự nhiền (NK) trong điều trị ung thư phổi" do trường Đại học Y Hà Nội chủ trì, PGS.TS Trần Huy Thịnh làm chủ nhiệm đề tài. Chúng tôi xin trân trọng cảm ơn.

\section{TÀI LIẸU THAM KHẢO}

1. Sung, H.; Ferlay, J.; Siegel, R. L.; Laversanne, M.; Soerjomataram, I.; Jemal, A.; Bray, F. Global Cancer Statistics 2020: GLOBOCAN Estimates of Incidence and Mortality Worldwide for 36 Cancers in 185 Countries. CA Cancer J Clin 2021.

2. Oh, S.; Lee, J.-H.; Kwack, K.; Choi, S.-W. Natural
Killer Cell Therapy: A New Treatment Paradigm for Solid Tumors. Cancers (Basel) 2019, 11 (10).

3. Suen, W. C.-W.; Lee, W. Y.-W.; Leung, K.-T.; Pan, X.-H.; Li, G. Natural Killer Cell-Based Cancer Immunotherapy: A Review on 10 Years Completed Clinical Trials. Cancer Invest 2018, 36 (8), 431-457.

4. Imai, K.; Matsuyama, S.; Miyake, S.; Suga, K.; Nakachi, K. Natural Cytotoxic Activity of Peripheral-Blood Lymphocytes and Cancer Incidence: An 11-Year Follow-up Study of a General Population. Lancet 2000, 356 (9244), 1795-1799.

5. Lê Thu Hà. Đánh Giá Hiệu Quả Thuốc Erlotinib Trong Điều Tri Ung Thư Phổi Biểu Mô Tuyến Giai Đoạn Muộn; Luận án Tiến sỹ y học, Trương Đại hợ y Hà Nội., 2017.

6. Xie, S.; Wu, Z.; Niu, L.; Chen, J.; Ma, Y.; Zhang, M. Preparation of Highly Activated Natural Killer Cells for Advanced Lung Cancer Therapy. Onco Targets Ther 2019, 12, 5077-5086.

7. Liem, N. T.; Van Phong, N.; Kien, N. T.; Anh, B. V.; Huyen, T. L.; Thao, C. T.; Tu, N. D.; Hiep, D. T.; Hoai Thu, D. T.; Nhung, H. T. M. Phase I Clinical Trial Úsing Autologous Ex Vivo Expanded NK Cells and Cytotoxic T Lymphocytes for Cancer Treatment in Vietnam. Int $\mathrm{J}$ Mol Sci 2019, 20 (13).

8. Iyer, S.; Taylor-Stokes, G.; Roughley, A. Symptom Burden and Quality of Life in Advanced Non-Small Cell Lung Cancer Patients in France and Germany. Lung Cancer 2013, 81 (2), 288-293.

9. Tian, W.; Zhang, P.; Yuan, Y.; Deng, X.; Yue, $\mathbf{R . ;} \mathbf{G e}, \mathbf{X}$. Efficacy and Safety of Ceritinib in Anaplastic Lymphoma Kinase-rearranged Non-small Cell Lung Cancer: A Systematic Review and Meta-analysis. J Clin Pharm Ther 2020, 45 (4), 743-754.

\title{
MỐI TƯƠNG QUAN GIỮA MỨC Độ PHÂN MẢNH DNA TINH TRÙNG VÀ KẾT QUẢ THỤ TINH TRONG ỐNG NGHIỆM
}

\author{
Nguyễn Thị Hiệp Tuyết ${ }^{1}$, Nguyễn Văn Trung ${ }^{2}$, \\ Nguyễn Thị Thái Thanh², Đặng Thị Hồng Nhạn², Lê Minh Tâm²,3
}

TÓM TẮT

Mục tiêu: Đánh giá mối tương quan giữa phân mảnh DNA tinh trùng và kết quả phôi ở kỹ thuật tiêm tinh trùng vào bào tương noãn (ICSI). Đối tượng và phương pháp nghiên cứu: Nghiên cứu mô tả cắt ngang thực hiện trên 175 các cặp vợ chồng điều trị vô

${ }^{1}$ Ttrường Đại học Y Dược - Đại hoc Huê

${ }^{2}$ Trung tâm Nội tiết Sinh sản và Vô sinh, Bệnh viện trường Đại học Y Dược Huế

${ }^{3}$ Trường Đai hoc Y Dước Huế

Chịu trách nhiệm chính: Nguyễn Thị Hiệp Tuyết

Email: nguyenthihieptuyet@tump.edu.vn

Ngày nhận bài: 9.3.2021

Ngày phản biên khoa học: 26.4.2021

Ngày duyệt bài: 6.5 .2021 sinh bằng phương pháp ICSI tai Trung tâm Nôi tiết Sinh sản và Vô sinh, Bệnh viện trường Đại học Y Dược Huế. Đánh giá DNA tinh trùng bằng kỹ thuật phân tản chất nhiễm sắc, mức độ phân mảnh DNA tinh trùng được tính giá trị chỉ số phân mảnh (DFI - DNA fragmentation index). Sau khi ICSI $16-18$ giờ, các tế bào trứng đã thụ tinh được xác định bởi sự hiện diện của hai tiên nhân. Phôi được đánh giá theo sự đồng thuận của Istanbul (2011) vào ngày thứ 2 và 5 . Kết quả: Tỷ lệ thụ tinh ở nhóm DFI $\geq 30 \%$ thấp hơn có ý nghĩa thống kê so với nhóm DFI <30\% (80.27 $\pm 17.47 \%$ vs $74.48 \pm 17.32 \%, p=0,046)$. Không có sự khác biệt có ý nghĩa thống kê giữa hai nhóm về đăc điểm phổi ngày 2 , ngày 5 . Mức đô phân mảnh DNA tinh trùng có mối tương quan nghịch với tỷ lệ thụ tinh sau ICSI ( $r=-0.185, p=0.014)$, phương trình hồi quy tuyến tính: $y=-0.187 x+83.55$. Kết luận: Sự 
phân mảnh DNA tinh trùng có mối tương quan nghịch với tỷ lệ thụ tinh sau ICSI. Xét nghiệm phân mảnh DNA tinh trùng có giá trị góp phần tiên lượng kết quả trong điều tri vô sinh.

Tư khóa: Phân mảnh DNA tinh trùng, tiệm tinh trùng vào bào tương noãn, phân tán chất nhiếm sắc, phôi nang.

\section{SUMMARY}

THE CORRELATION BETWEEN THE SPERM FRAGMENTATION DNA AND THE OUTCOME OF IN VITRO FERTILISATION

Objective: To evaluate the correlation between the sperm fragmentation DNA and the outcome of the intracytoplasmic sperm injection (ICSI) technique. Materials and methods: The descriptive crosssectional study on 175 infertile couples by ICSI method at the Center for Reproductive Endocrinology and Infertility, Hue University Hospital. Evaluation of sperm DNA fragmentation by using sperm chromatin dispersion technique, the level of sperm DNA fragmentation is calculated by the value of the fragmentation index (DFI - DNA fragmentation index). After 16-18 hours of injection, the fertilized oocytes were determined by the presence of two pronuclei. Embryos were evaluated according to Istanbul consensus on the day 2 and 5. Results: The rate of fertilization in group DFI $\geq 30 \%$ was difference statistically lower than in DFI group $<30 \%(80.27 \pm$ $17.47 \%$ vs. $74.48 \pm 17.32 \%, p=0.046)$. There was no difference statistically between the two groups DFI for the quality of embryos on day 2, and day 5 . Sperm DNA fragmentation had a correlation with the fertilization rate $(r=-0.185, p=0.014)$, linear regression equation: $y=-0.187 x+83.55$. Conclusion: Sperm DNA fragmentation has a negative correlation with post-ICSI fertilization rates. Sperm DNA fragmentation assay has a valuation in predict the results of infertile treatment.

Keyword: Sperm DNA fragmentation, Intracytoplasmic sperm injection, sperm chromatin dispersion, blastocyst

\section{I. ĐĂT VẤN ĐỀ}

Hơn $15 \%$ các cặp vợ chồng trên toàn thế giới gặp vấn đề về khả năng sinh sản và $50 \%$ các trường hợp này là do nguyên nhân vô sinh nam [3]. DNA (Deoxyribonucleic acid) tinh trùng liên quan mật thiết tới khả năng thụ tinh và sự phát triển của phôi. Người nam giới vô sinh có mức đô phân mảnh DNA tinh trùng cao hơn so với những người có khả năng sinh sản bình thường, việc thụ tinh ở tinh trùng bị phân mảnh DNA có thể làm tăng nguy cơ mắc các bệnh di truyền ở thế hệ sau. Trong hỗ trợ sinh sản (HTSS) và nam học, xét nghiệm phân mảnh DNA tinh trùng được đề xuất trong tìm nguyên nhân, chẩn đoán ở những trường hợp vô sinh không rõ nguyên nhân, thất bại làm tổ nhiều lần, giãn tĩnh mạch thừng tinh.... Giá trị của phân mảnh DNA tinh trùng như là một chỉ số độc lập để đánh giá chất lượng tinh trùng nên nhiều trung tâm HTSS đưa vào các quy trình phân tích tinh dịch. Ảnh hưởng của chỉ số phân mảnh DNA (DFI) tinh trùng đến khả năng thụ tinh và sự phát triển của phôi vẫn còn chưa rõ ràng. Trong một số nghiên cứu đưa ra kết quả cho thấy phân mảnh DNA tinh trùng không làm giảm tỷ lệ có thai ở kỹ thuật tiêm tinh trùng vào bào tương noãn (ICSI) [9]. Tuy nhiên, một số khác báo cáo phân mảnh DNA của tinh trùng có liên quan đến chất lượng phôi và/hoặc sự phát triển của phôi sau chuyển phôi [4]. Hiện nay, ở Việt Nam một số trung tâm HTSS và Y sinh học đã đang tiến hành đánh giá sự phân mảnh DNA tinh trùng và nồng độ chất oxy hóa trong mẫu tinh dịch ở nhiều nhóm bênh nhân khác nhau. Tuy nhiên, còn khá ít các nghiên cứu chuyên sâu, thực hiện trên nhiều mẫu bệnh nhân có thực hiện HTSS để đánh giá mối tương quan giữa sự phân mảnh DNA tinh trùng và chất lượng phôi. Vì vậy, chúng tôi thực hiện nghiên cứu này với mục tiêu: "Đánh giá mối tương quan giữa phân mảnh DNA tinh tùng và kết quả phôi ở kỹ thuật tiêm tinh trùng vào bào tương noãn (ICSI)".

\section{II. ĐỐI TƯỢNG VÀ PHƯƠNG PHÁP NGHIÊN CỨU}

Nghiên cứu mô tả cắt ngang thực hiện trên 175 các cặp vợ chồng điều trị vổ sinh bằng phương pháp ICSI tại Trung tâm Nội tiết Sinh sản và Vô sinh, Bệnh viện trường Đại học $Y$ Dược Huế. Thời gian từ 02/2020 đến 12/2020.

- Các biến số nghiên cứu:

+ Thông số tinh dịch đồ: pH, thể tích, mật độ, độ di động, tỷ lệ sống, hình thái được đánh giá theo hướng dấn của WHO (2010)

+ Đánh giá mức độ phân mảnh DNA tinh trùng: mẫu tinh dịch được phân tích DNA dựa trên kỹ thuật phân tán chất nhiễm sắc, được cung cấp bởi Halostech. Đánh giá phân mảnh DNA dựa vào quầng halo tại đầu tinh trùng. Tiêu chí phẩn loại: (1): Tinh trùng có quầng halo lớn: Kích thước quầng halo $\geq$ đường kính ngang của nhân; (2): Tinh trùng có quâng halo trung bình: $1 / 3$ đường kính ngang của nhân < kích thước quầng halo < đường kính ngang của nhân; (3): Tinh trùng có quầng halo nhỏ: Kích thước quâng halo $\leq 1 / 3$ đường kính ngang của nhân; (4): Tinh trùng không có quầng halo; (5): Tinh trùng thoái hóa: Tinh trùng có nhân bắt màu kém, không đều.

Chỉ số DFI được tính theo công thức:

(TT - Tinh trùng)

DFI $(\%)=\Pi$ có halo nhỏ $+\Pi$ không có halo + TT nhân thoái hóa/ TT đếm được

Chia nhóm nghiên cứu dựa theo giá trị DFI: 
Dựa trên khuyến nghị của Halotech cung cấp, ngưỡng DFI $30 \%$ để phân biệt giữa hai nhóm: nhóm DFI $\geq 30 \%$ (mức độ phẩn mảnh DNA cao) và nhóm DFI <30\% (mức độ phân mảnh DNA trung bình và thấp)

+ Kỹ thuật ICSI được thực hiện sau 3h thu nhận noãn và chuẩn bị tinh trùng. Tinh trùng chuẩn bị cho ICSI được thực hiện theo phương pháp thang nồng độ. Noãn sau ICSI được nuôi

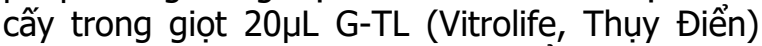
phủ $3 \mathrm{~mL}$ Ovoil (Vitrolife, Thụy Điển) trong điêu kiện $6,0 \%$ CO2 và $5,0 \%$ O2. Sau khi ICSI 16-18 giờ, các tế bào trứng đã thụ tinh được xác định bởi sự hiện diện của hai tiền nhân. Phôi được đánh giá theo sự đồng thuận của Istanbul vào ngày thứ 2 và $5[6]$.

- Phân tích thống kê được thực hiện bằng phần mềm SPSS (phiên bản 22.0, SPSS Inc). Giá trị trung bình, tỷ lệ phần trăm được so sánh giữa các nhóm. Hệ số tương quan của Pearson ( $r$ ) được đánh giá theo giá trị của phân mảnh DNA tinh trùng và kết quả thụ tinh.

\section{KẾT QUẢ NGHIÊN CỨU}

Bảng 1. Đặc điểm chung, thông số tinh dịch đồ và môi liên quan với mức độ tổn thương DNA tinh trùng

\begin{tabular}{|c|c|c|c|c|}
\hline Đặc điểm & $\begin{array}{c}\text { Tống } \\
N=175\end{array}$ & $\begin{array}{c}\text { DFI }<30 \% \\
\mathbf{N}=123\end{array}$ & $\begin{array}{c}\text { DFI } \geq 30 \% \\
N=52\end{array}$ & p \\
\hline \multicolumn{5}{|c|}{ Đặc điểm chung } \\
\hline Tuối chồng & $36.10 \pm 5.67(26-27)$ & $36.23 \pm 5.64$ & $35.87 \pm 5.70$ & 0.69 \\
\hline Tuối vơ & $33.23 \pm 4.59(21-47)$ & $33.38 \pm 4.56$ & $33.00 \pm 4.62$ & 0.79 \\
\hline \multicolumn{5}{|c|}{ Đặc điểm vố sinh } \\
\hline Vô sinh I & $150(85.7 \%)$ & $106(85.5 \%)$ & $44(86.3 \%)$ & \multirow{2}{*}{0.55} \\
\hline Vô sinh II & $25(14.3 \%)$ & $18(14.5 \%)$ & $7(13.7 \%)$ & \\
\hline Thời gian vô sinh(năm) & $5.01 \pm 2.66(1-13)$ & $5.09 \pm 2.58$ & $4.91 \pm 2.80$ & 0.696 \\
\hline \multicolumn{5}{|c|}{ Đặc điểm tinh dịch } \\
\hline Thể tích (ml) & $1.84 \pm 1.01(0.5-7.0)$ & $1.84 \pm 1.02$ & $1.88 \pm 0.98$ & 0.834 \\
\hline $\mathrm{pH}$ & $7.12 \pm 0.31(6.0-8.4)$ & $7.10 \pm 0.52$ & $7.08 \pm 0.30$ & 0.775 \\
\hline Mât đô $\left(10^{6} / \mathrm{ml}\right)$ & $31.09 \pm 14.11(3-73)$ & $32.44 \pm 14.13$ & $27.24 \pm 14.28$ & 0.028 \\
\hline Di động tiến tới (\%) & $29.14 \pm 12.08(2-58)$ & $29.92 \pm 11.07$ & $27.53 \pm 13.79$ & 0.228 \\
\hline Tỷ lệ sống (\%) & $78.97 \pm 8.93(25-95)$ & $79.41 \pm 8.71$ & $78.17 \pm 9.20$ & 0.399 \\
\hline Hình thái bình thường(\%) & $3.82 \pm 2.14(0-14)$ & $3.93 \pm 2.10$ & $3.50 \pm 2.31$ & 0.235 \\
\hline Bất thường đầu(\%) & $87.34 \pm 5.52(76-99)$ & $87.96 \pm 5.57$ & $88.42 \pm 5.56$ & 0.14 \\
\hline Bất thường cổ-đuôi (\%) & $58.74 \pm 11.10(30-87)$ & $58.90 \pm 10.26$ & $58.46 \pm 13.17$ & 0.812 \\
\hline \multicolumn{5}{|c|}{ Đặc điểm phân mảnh DNA } \\
\hline Quầng halo lớn & $32.07 \pm 20.79(0-89.6)$ & $38.26 \pm 20.95$ & $17.43 \pm 10.66$ & 0.00 \\
\hline Quầng halo trung bình & $43.20 \pm 18.25(4.6-86.2)$ & $46.32 \pm 19.16$ & $35.83 \pm 13.39$ & 0.00 \\
\hline DFI & $24.29 \pm 17.08(4.4-81.6)$ & $15.23 \pm 6.55$ & $46.23 \pm 14.80$ & 0.00 \\
\hline
\end{tabular}

Nhận xét: Tỷ lệ nam giới có có DFI cao $\geq 30 \%$ là $51 / 175$ (29.12\%). Các thông số tinh dịch không có sự khác biệt có ý nghĩa thông kê, ngoài trừ mật độ tinh trùng ở nhóm DFI cao có mật độ thấp hơn: DFI < 30\% (32.44 14 .13. $\left.10^{6} / \mathrm{ml}\right)$ vs DFI $\geq 30 \%\left(27.53 \pm 13.79 .10^{6} / \mathrm{ml}\right), \mathrm{p}=0.028$. Mức độ DFI trung bình ở các cặp vợ chồng vô sinh là $24.29 \pm 17.08 \%$, ở hai nhóm DFI cao và thấp lần lượt là: $15.23 \pm 6.55$ và $46.23 \pm 14.80(\mathrm{p}=0.00)$

Bảng 2. Mối liên quan giữa sự phát triển của phôi và mức độ phân mảnh DNA tinh trùng

\begin{tabular}{|c|c|c|c|c|}
\hline Đặc điểm & $\begin{array}{c}\text { Tổng } \\
\text { N=175 }\end{array}$ & $\begin{array}{c}\text { DFI }<30 \% \\
N=123\end{array}$ & $\begin{aligned} \text { DFI } & \geq 30 \% \\
N & =52\end{aligned}$ & p \\
\hline Số noãn MII & $13.38 \pm 7.32(5-39)$ & $12.95 \pm 7.14$ & $14.59 \pm 7.59$ & 0.231 \\
\hline Số noãn & $10.23 \pm 5.61(1-30)$ & $10.10 \pm 5.64$ & $10.59 \pm 7.59$ & 0.60 \\
\hline Tỷ lệ thụ tinh bình thường & $77.97 \pm 17.48(16.67-100)$ & $80.27 \pm 17.47$ & $74.48 \pm 17.32$ & 0.046 \\
\hline \multicolumn{5}{|c|}{ Đánh giá phôi ngày 2} \\
\hline Tổng số phôi & $9.85 \pm 5.55(1-30)$ & $9.62 \pm 5.56$ & $10.29 \pm 5.59$ & 0.468 \\
\hline Tỷ lệ phôi < 4 tế bào & $22.04 \pm 19.69(0-100)$ & $23.42 \pm 20.01$ & $19.69 \pm 18.70$ & 0.253 \\
\hline Tý lề phôi $\geq 4$ tế bào & $78.24 \pm 19.33(14.29-100)$ & $76.67 \pm 19.39$ & $80.85 \pm 18.84$ & 0.191 \\
\hline Tý lệ mảnh vỡ < 10\% & $22.04 \pm 19.69(0-100)$ & $80.41 \pm 22.28$ & $80.09 \pm 24.18$ & 0.932 \\
\hline
\end{tabular}




\begin{tabular}{|c|c|c|c|c|}
\hline Tỷ lệ mảnh võ $10-20 \%$ & $14.18 \pm 17.09(0.00-66.67)$ & $13.81 \pm 16.91$ & $15.03 \pm 17.63$ & 0.669 \\
\hline Tỳ lệ mảnh vỡ > 20\% & $5.25 \pm 10.64(0-71.34)$ & $5.76 \pm 11.04$ & $4.06 \pm 9.65$ & 0.336 \\
\hline \multicolumn{5}{|c|}{ Đánh giá phôi ngày 5 } \\
\hline Tống số phôi ngày 5 & $9.92 \pm 5.60(1-31)$ & $9.70 \pm 5.62$ & $10.37 \pm 5.57$ & 0.474 \\
\hline Tỷ lệ tạo phôi nang hữu dụng & $84.33 \pm 20.64(0-100)$ & $85.93 \pm 18.43$ & $79.97 \pm 25.39$ & 0.081 \\
\hline Tỷ lệ tạo nang tốt & $55.60 \pm 26.08(0-100)$ & $56.00 \pm 25.18$ & $53.33 \pm 28.54$ & 0.539 \\
\hline
\end{tabular}

Nhân xét: Tỷ lệ thụ tinh ở nhóm DFI $\geq 30 \%$ thấp hơn có ý nghĩa thống kê so với nhóm DFI $<30 \%(80.27 \pm 17.47 \%$ vs $74.48 \pm 17.32 \%, p=0,046)$. Không có sự khác biệt có ý nghĩa thống kê giữa hai nhóm về đặc điểm phôi ngày 2 . Tỷ lệ tạo phôi nang hữu dụng ở nhóm DFI $\geq 30 \%$ thấp hơn

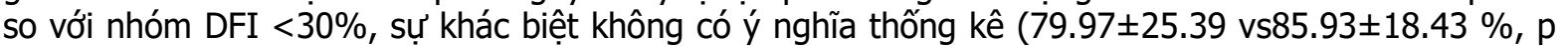
$=0.081$ )

Bảng 3. Môii tương quan giữa đặc điểm phân mảnh DNA tinh trùng và kêt quả thụ tinh

\begin{tabular}{|c|c|c|c|c|}
\hline & $\begin{array}{c}\text { Quâng } \\
\text { halo lớn }\end{array}$ & $\begin{array}{l}\text { Quâng } \\
\text { halo } \\
\text { trung }\end{array}$ & DFI \\
\hline \multirow{2}{*}{$\begin{array}{l}\text { Tỷ lệ thụ } \\
\text { tinh }\end{array}$} & $r$ & 0.039 & 0.134 & -0.185 \\
\hline & $p$ & 0.606 & 0.077 & 0.014 \\
\hline \multirow{2}{*}{$\begin{array}{l}\text { Tỷ lệ tạo } \\
\text { phôi nang } \\
\text { hữu dung }\end{array}$} & $r$ & 0.001 & 0.081 & -0.101 \\
\hline & $p$ & 0.990 & 0.284 & 0.186 \\
\hline \multirow{2}{*}{$\begin{array}{l}\text { Tỷ lệ tạo } \\
\text { nang tốt }\end{array}$} & $r$ & -0.096 & 0.144 & -0.027 \\
\hline & $p$ & 0.208 & 0.058 & 0.718 \\
\hline
\end{tabular}

Nhận xét: Mức độ phân mảnh DNA tinh trùng có mối tương quan nghịch với tỷ lệ thụ tinh sau ICSI.

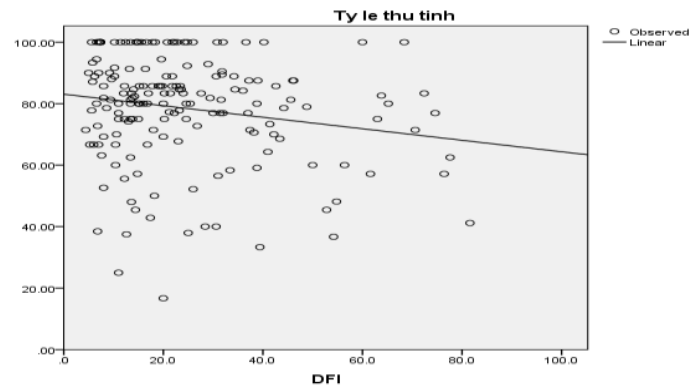

Biểu đồ 1. Môi tương quan giữa DFI và tỷ lệ thu tinh:

Phương trinh hồi quy tuyến tính: $y=-0.187 x$ $+83.55$

\section{BÀN LUÂN}

Ảnh hưởng của phân mảnh DNA tinh trùng đến chất lượng phôi trong các chu kỳ ICSI vẫn còn là một vấn đề gây tranh cãi. Trong phương pháp ICSI, tinh trùng được chọn dựa trên khả năng di chuyển và hình thái, do vậy tinh trùng được tiêm bào tương của noãn đã vượt qua một số rào cản của chọn lọc tự nhiên. Các nghiên cứu gần đây cho thấy tác động gián tiếp của tổn thương DNA tinh trùng đối với quá trình thụ tinh và phát triển phôi sớm thông qua quá trình sửa chữa vật chất di truyền xảy ra trong tế bào trứng. Do đó, sư phát triển của phôi có thể bi trì hoãn và chất lượng phôi kém được tìm thấy ở nhóm có DFI cao. Kết quả của chúng tôi ghi nhận tỷ lệ thụ tinh ở nhóm có DFI $\geq 30 \%$ thấp hơn có ý nghĩa thống kê so với ở nhóm DFI $<30 \%$. Khi đánh giá mối tương quan, kết quả chỉ ra rằng giữa mức độ phân mảnh DNA tinh trùng với kết quả thụ tinh có mối tương quan nghịch: $r=-0.185, p=0.014$, với phương trình hồi quy tuyến tính là: $y=-0.187 x+83.55$. Nghiên cứu của tác giả Borges và cộng sự (2019) báo cáo kết quả ICSI từ nhóm bệnh nhân có DFI $\geq 30 \%$ có tỷ lệ thụ tinh, tốc đô phân cắt bình thường và tỷ lệ phôi tốt vào ngày thứ 3 giảm có ý nghĩa thống kê so với nhóm có DFI <30\%[8]. Một nghiên cứu tại Việt Nam, cũng báo cáo có mối tương quan nghich giữa DFI và tỷ lê thu tinh sau ICSI [1], tuy nhiên một nghiên cứu khác đưa ra kết quả không ghi nhận các chỉ số của ICSI bao gồm: tỷ lệ thụ tinh, tỷ lệ tạo phôi ngày 3 , tỷ lệ tạo phôi hữu dụng ngày 3 , các kết quả sau chuyển phôi ngày 3 không chịu ảnh hưởng bới mức độ phân mảnh DNA tinh trùng[2]. Tuy nhiên, có báo cáo cho thấy việc phân mảnh DNA không ảnh hưởng đến kết quả thụ tinh và phát triển phôi sớm cho đến khi hình thành phôi nang [5].

Trong nghiên cứu này, chúng tôi không ghi nhận sự khác biệt có ý nghĩa thống kê ở 2 nhóm DFI ở các kết quả phát triển phôi ngày 2 và ngày 5. Tuy nhiên, kết quả thể hiên xu hướng có ý nghĩa thông kê ở tỷ lệ tạo phôi nang hữu dụng, ở nhóm DFI $\geq 30 \%$ có tỷ lệ tạo phôi nang hữu dụng thấp hơn so với nhóm DFI $<30 \%, p=$ 0.081. Ở một số nghiên cứu chỉ ra mức đô phân mảnh DNA tinh trùng có ảnh hưởng tới chất lượng phôi sau ICSI: Sivanarayana và cộng sự (2013), số lượng phôi tiến triển đến ngày 3 và tốc độ hình thành phôi nang ghi nhân thấy giá trị cao hơn ở nhóm phân mảnh DNA bình thường ( $\mathrm{p}$ $<0,05)$. Simon và cộng sự (2014), báo cáo trong giai đoạn phôi ngày $1-2$ và $3-5$ thì nhóm phân mảnh DNA thấp có tỷ lệ phôi chất lượng tốt 
cao hơn $(p<0,05)$ và tỷ lệ phôi chất lượng kém $(p<0,05)$ thấp hơn so với nhóm có phẩn mảnh DNA cao. Alvarez Sedó và cộng sự (2017) nghiên cứu có mối tương quan nghịch $(r=-0,5)$ giữa sự phân mảnh DNA và tỷ lệ tạo phôi nang sau ICSI.

Bên cạnh đánh giá mối liên quan giữa phân mảnh DNA tinh trùng và kết quả phôi, chúng tôi đồng thời đánh giá mối liên quan với thông số tinh dịch đồ thường quy. Kết quả cho thấy có sự khác biệt có ý nghĩa thống kê về mật độ tinh trùng giứu hai nhóm DFI, $p=0.028$. Tinh dịch đồ là phương pháp thường quy nhưng còn hạn chế về dự đoán khả năng sinh sản, cũng như giải thích được đây đủ nguyên nhân gây vô sinh nam. Mối liên quan giữa DFI và các thông số tinh dịch vẫn chưa rõ ràng và khác nhau ở mối nghiên cứu. Trong khi một số nghiên cứu báo cáo mối tương quan chặt chẽ $[10],[12]$, nhưng những nghiên cứu khác không thấy có mối liên quan nào giữa DFI và các thông số tinh dịch đồ. Nghiên cứu của tác giả Borges và cộng sự báo cáo: thể tích tinh dịch ở nhóm DFI <30\% thấp hơn có ý nghĩa thống kê so với nhóm DFI $\geq 30 \%$ (2.94 \pm 0.50 so với $3.79 \pm 1.09, p=0.001$ ), độ động tiến tới nhóm DFI < $30 \%$ cao hơn có ý nghĩa so với so với nhóm DFI $\geq 30 \%$ (54.90 $\pm 14.27 \%$ so với $46.50 \pm 16.77 \%, p=0.001$ ) [8]. Sivanarayana và cộng sự ghi nhận DFI có mối tương quan nghịch với các thông số tinh dịch: nồng độ, khả năng di động và hình thái bình thường thấp hơn đáng kể ở nhóm có DFI cao so với nhóm DFI bình thường. Ngược lại, một số nghiên cứu khác không có mối tương quan giữa các thông số tinh dịch và DFI. Thậm chí, ở những người nam giới có mật độ tinh trùng dưới ngưỡng, không có mối tương quan giữa sự phân mảnh DNA tinh trùng và di động, mật độ và hình thái [7].

Với số lượng cõ mẫu và phương pháp xét nghiệm DNA tinh trùng khác nhau ở các nghiên cứu, dẫn đến sự khác nhau về mối liên quan giữa mức độ phẩn mảnh DNA tinh trùng đến kết quả sau ICSI. Trong nghiên cứu này, chúng tôi đồng quan điểm nhận định rằng với những tinh trùng có phân mảnh DNA, khi được chọn để ICSI tác động ảnh hưởng đến khả nẳng thụ tinh, vì giai đoạn sớm này phụ thuộc vào chất lượng của giao tử đực và cái. Giá trị của xét nghiệm DNA tinh trùng trong dự đoán các kết quả được coi là có liên quan đến mức độ và loại tổn thương DNA cũng như DNA tinh trùng vốn có khả năng sửa chữa của tế bào trứng sau thụ tinh. Khả năng của tế bào trứng để tự sửa chữa tổn thương DNA của tinh trùng thụ tinh phụ thuộc vào chất lượng tế bào chất và bộ gen của noãn, yếu tố này bi ảnh hưởng bởi dự trữ buồng trứng kém và tuổi mẹ.

\section{KẾT LUÂ̂N}

Sự phân mảnh DNA tinh trùng có mối tương quan nghịch với tỷ lệ thụ tinh sau ICSI. Chưa ghi nhân mối liên quan, mối tương quan giữa phân mảnh DAN tinh trùng và sự phát triển phôi ngày 2 và ngày 5 . Xét nghiệm phân mảnh DNA tinh trùng có giá trị trong chẩn đoán vô sinh, giải thích nguyên nhân dẫn đến thất bại trong hỗ trợ sinh sản, góp phần tiên lượng kết quả trong điều trị vô sinh.

Lời cảm ơn: "Nghiên cứu sinh Nguyễn Thị Hiệp Tuyết được tài trợ bởi Nhà tài trợ thuộc Tập đoàn Vingroup và hỗ trợ bởi chương trình học bổng đào tạo thạc sĩ, tiến sĩ trong nước của Quỹ Đổi mới sáng tạo Vingroup (VINIF), Viện Nghiên cứu Dữ liệu lớn (VinBigdata), mã số VINIF.2020.TS.44"

\section{TÀI LIÊU THAM KHẢO}

1. Nguyễn Minh Tài Lộc, Mã Phạm Quế Mai Nguyển Ân Bình và công sự. (2016). "Mối tương quan giữa kết quả tiêm tinh trùng vào bào tương noãn và sự phân mảnh DNA tinh trùng đước đo bănng phương pháp khảo sát cấu trúc nhiếm sằc chất tinh trùng (SCSA) " Tạp chí Phụ Sản. 14(04): $70-74$.

2. Nguyễn Thị Quỳnh Tiên, Mã Phạm Quế Mai, Dương Nguyến Duy Tuyên và cộng sứ (2018). "Mối tương quan của chỉ số phẩn mảnh DNA tinh trùng và kết quả tiêm tinh trùng vào bào tương noãn." Tạp chí Phụ Sản. 15(4): 89 - 93.

3. Agarwal A, Mulgund $A$, Hamada $A$, et al. (2015). "A unique view on male infertility around the globe." Reprod Biol Endocrinol: 1-9.

4. Avendano $C$, Franchi $A$, Duran $H$, et al. (2010). "DNA fragmentation of normal spermatozoa negatively impacts embryo quality and intracytoplasmic sperm injection outcome." Fertil Steril. 94(2): 549-557.

5. Bach PV and Schlegel PN (2016). "Sperm DNA damage and its role in IVF and ICSI." Basic Clin Androl. 26: 15.

6. Balaban $B$, Brison $D$, Calderon $G$, et al. (2011). "The Istanbul consensus workshop on embryo assessment: Proceedings of an expert meeting." Human Reproduction. 26: 1270-1283.

7. Belloc Stephanie, Benkhalifa Moncef, CohenBacrie Martine, et al. (2014). "Which isolated sperm abnormality is most related to sperm DNA damage in men presenting for infertility evaluation." Journal of assisted reproduction and genetics. 31(5): 527-532.

8. Borges EJr, Zanetti BF, Setti AS, et al. (2019). "Sperm DNA fragmentation is correlated with poor embryo development, lower implantation rate, and higher miscarriage rate in reproductive cycles of non-male factor infertility." Fertil Steril. 112(3): 483-490. 